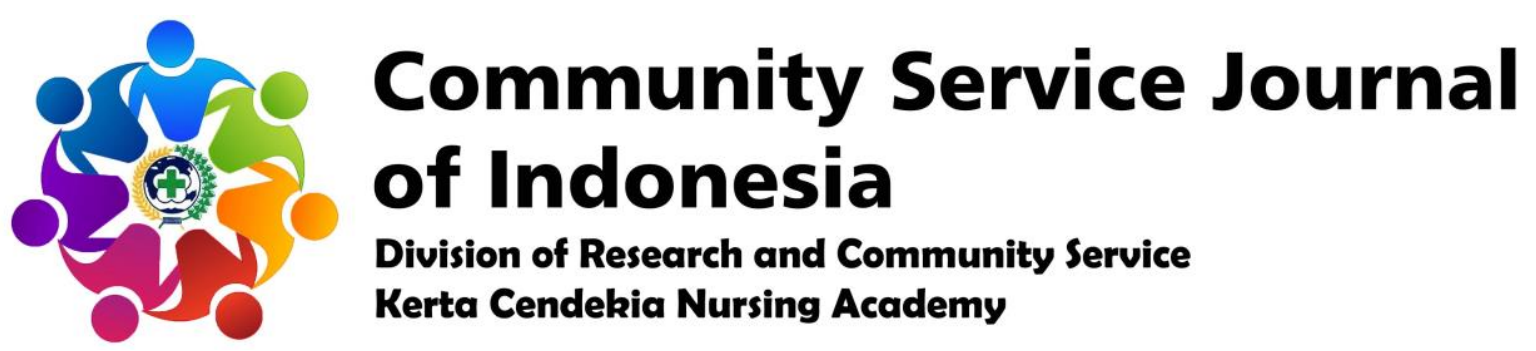

https://ejournal-kertacendekia.id/index.php/csji/index

\author{
Community Service Journal of Indonesia 3 (2) (2021): 37-40 \\ Doi: https://doi.org/10.36720/csji.v3i2.354
}

\title{
IMPLEMENTATION OF VACCINATION FOR THE GENERAL COMMUNITY AT THE CAMPUS OF THE HEALTH POLYTECHNIC OF KERTA CENDEKIA
}

\section{Dimas Hadi Prayoga 1, Kusuma Wijaya Ridi Putra 1, Riesmiyatiningdyah Riesmiyatiningdyah ${ }^{1}$, Meli Diana ${ }^{1}$, Dini Prastyo Wijayanti ${ }^{1}$, Agus Sulistyowati ${ }^{1}$, Nina Rizka Rohmawati ${ }^{1}$, Nima Eka Nur Rahmania ${ }^{1}$}

${ }^{1}$ Health Polytechnic of Kerta Cendekia, Sidoarjo, East Java Province, Indonesia

\author{
* Correspondence \\ Kusuma Wijaya Ridi Putra \\ Health Polytechnic of Kerta Cendekia, Sidoarjo
}

Lingkar Timur Road, Rangkah Kidul Village, Sidoarjo Sub District, Sidoarjo District, East Java Province, Indonesia, 61272

Email: ridiputra@hotmail.com

\begin{abstract}
The public vaccination activity carried out within the Health Polytechnic of Kerta Cendekia is a form of the active role of the academic community of the Health Polytechnic of Kerta Cendekia in dealing with Covid-19 and supports the accelerated vaccination program carried out by the Government of Indonesia. The activity will be held on September 17, 2021, at the Health Polytechnic of Kerta Cendekia Campus. The target of this vaccination activity is the academic community of the Health Polytechnic of Kerta Cendekia and the community around the campus who need vaccines, both the first and second doses. This activity was held in collaboration with the Health Polytechnic of Kerta Cendekia with the Sidoarjo District Health Office. This vaccination activity was attended by 176 people who attended to vaccinate, both the first dose and the second dose. The activity starts at $9.20 \mathrm{WIB}$ and ends at 14.00 WIB. This activity has involved 9 lecturers, 4 staff, and 14 students. In addition, this activity also involved 4 alumni who acted as vaccinators. The activity ran smoothly, in an orderly manner, and still implemented physical distancing in its implementation.
\end{abstract}

Keywords: Vaccination, COVID-19, Community Service.

(c) 2021 The Authors. Community Service Journal of Indonesia Published by Institute for Research and Community Service,

Health Polytechnic of Kerta Cendekia, Sidoarjo

This is an Open Access Article distributed under the terms of the Creative Commons Attribution-NonCommercial 4.0 (CC

BY-NC 4.0), which allows others to remix, tweak, and build upon the work non-commercially as long as the original work is

properly cited. The new creations are not necessarily licensed under the identical terms.

E-ISSN

2684-7884

P-ISSN

2774-4027 


\section{INTRODUCTION}

The Covid-19 pandemic is a situation that is a shared responsibility. To overcome this, cooperation from all parties is needed, both the central government, regional governments, related agencies, the academic community, and the community in general. The Health Polytechnic of Kerta Cendekia as one of the universities in the health sector, wishes to play an active role in overcoming the Covid-19 pandemic. One form of its active role, the Health Polytechnic of Kerta Cendekia carries out vaccination activities for the public which are held at the Health Polytechnic of Kerta Cendekia Campus. This vaccination activity is intended to support the accelerated vaccination program carried out by the Government of Indonesia, so that the Herd Community in Indonesia is immediately formed.

\section{OBJECTIVES}

\section{General Purpose}

This vaccination activity aims to assist the government in implementing COVID19 vaccination, especially for the academic community of the Health Polytechnic of Kerta Cendekia and the surrounding community.

\section{Special Purpose}

This activity aims to enable the academic community of the Kerta Cendekia Health Polytechnic to:

1. Gain immunity against COVID-19.

2. The implementation of offline learning.

\section{PLAN OF ACTION}

\section{Strategy Plan}

There were several strategies plans to implement the community service:

1. Coordination with the Sidoarjo District Health Office for the implementation of vaccinations that will be carried out in the Health Polytechnic of Kerta Cendekia Campus.

2. To attract vaccination enthusiasts to submit the number of vaccine doses to the Health Office of Sidoarjo Regency.

3. Internal coordination of activity implementers for the division of tasks during vaccination activities.

4. Implementation of general vaccination in the Health Polytechnic of Kerta Cendekia.

\section{Implementation}

The implementation of this vaccination activity includes several stages, including:

1. Coordinated with the Sidoarjo District Health Office for the implementation of vaccinations that will be carried out in the Health Polytechnic of Kerta Cendekia Campus.

2. Conducted screening for vaccination enthusiasts to submit the number of vaccine doses to the Sidoarjo Regency Health Office using Google Forms.

3. Carried out internal coordination of activity implementers for the division of tasks during vaccination activities.

4. Carried out general vaccination activities within the Health Polytechnic of Kerta Cendekia.

\section{Setting}

This vaccination activity was carried out at the Health Polytechnic of Kerta Cendekia Campus on September 17, 2021.

Target

The targets for the vaccinations carried out by the Health Polytechnic of Kerta Cendekia are the entire academic community of the Health Polytechnic of Kerta Cendekia who have not received 
previous vaccinations, Kerta Cendekia Vocational High School students, Kerta Cendekia Vocational School teachers, and the community around the Health Polytechnic of Kerta Cendekia Health Polytechnic

\section{RESULTS AND DISCUSSION}

The activity was carried out on September 17, 2021, starting at 9.20 WIB and ending at 14.00 , the counseling time had to be postponed for 20 minutes from the original schedule due to waiting for vaccines to take and buying alcohol swabs. The activity was carried out at the Health Polytechnic of Kerta Cendekia Campus. The activity was attended by 176 vaccination participants, 4 alumni as vaccinators, 14 students as committees, 9 lecturers, 4 educational staff, 4 NGOs (PCare) who were observed by the Regent of Sidoarjo Regency as documentaries and additional staff, and 1 officer from the Health Service of Sidoarjo Regency. The Sidoarjo Regency Government through the Sidoarjo Regency Health Office gave a fairly good response to the implementation of vaccination activities carried out at the Health Polytechnic of Kerta Cendekia Campus, Sidoarjo. Equipment and facilities used during the implementation of vaccination are ready. It's just that there is a little miscommunication for the provision of alcohol swabs. The implementation was quite orderly and the participants responded very enthusiastically. Activities in the form of vaccination, both the first dose and the second dose. Participants did not show symptoms after administering the vaccine after 20 minutes of observation. All vaccine participants have come to carry out vaccinations according to the schedule given by the committee, there are even a few additional participants who take part in vaccinations organized by the Health Polytechnic of Kerta Cendekia.

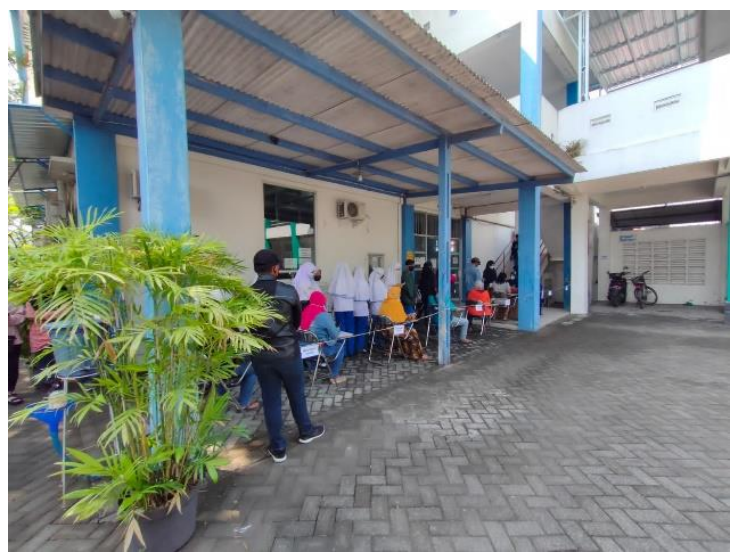

Picture 1. Queue Waiting for Reregistration of COVID-19 Vaccination at the Health Polytechnic of Kerta Cendekia.

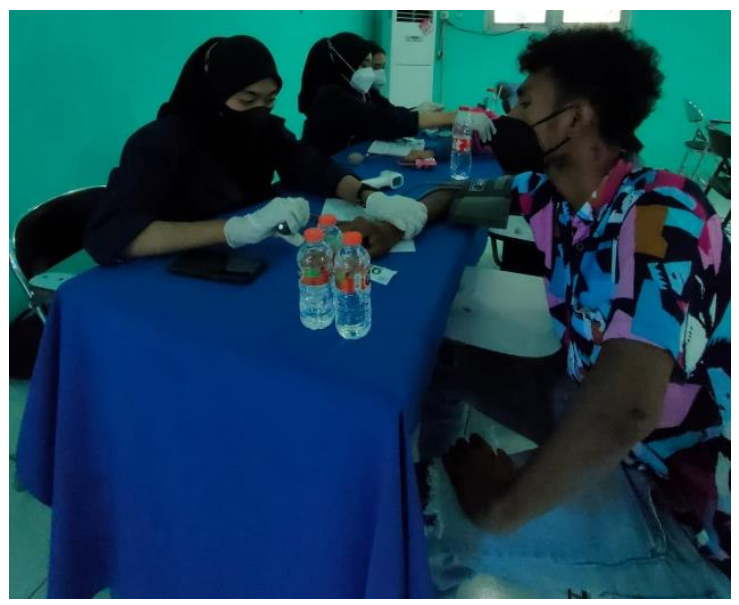

Picture 2. Initial Examination Before COVID-19 Vaccination.

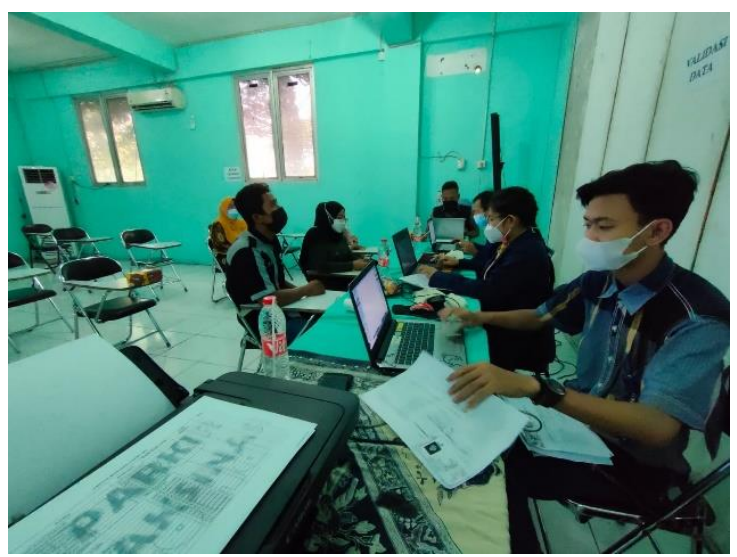

Picture 3. Data Validation for Vaccination Reporting in the Indonesian Government System. 


\section{CONCLUSION}

With the implementation of the COVID-19 Vaccination activity, it will provide immunity for vaccine recipients. However, this did not prevent him from contracting COVID-19. The COVID-19 vaccine that is given only reduces the impact given by COVID-19.

\section{REFERENCES}

Astuti, N. P., Nugroho, E. G. Z., Lattu, J. C., Potempu, I. R., \& Swandana, D. A. (2021). Persepsi Masyarakat terhadap Penerimaan Vaksinasi Covid-19: Literature Review. Jurnal Keperawatan, 13(3), 569-580.

Dewi, S. A. E. (2021). Komunikasi Publik Terkait Vaksinasi Covid 19. Health Care: Jurnal Kesehatan, 10(1), 162167.

Lamirin, L., Nuriani, N., Sentosa, H., \& Liana, L. (2021). Sosialisasi Dan Vaksinasi COVID-19 Kepada Tenaga Pendidik Serta Kependidikan Di Perguruan Buddhis Bodhicitta Medan. Jurnal Pengabdian Kepada Masyarakat Bodhi Dharma, 1(1), 2128.

Ritunga, I., Lestari, S. H., Santoso, J. L., Effendy, L. V., Siahaan, S. C. P. T., Lindarto, W. W., ... \& Monica, T. (2021). Penguatan Program Vaksinasi Covid-19 Di Wilayah Puskesmas Made Surabaya Barat. Jurnal ABDINUS: Jurnal Pengabdian Nusantara, 5(1), 45-52.

Sukmana, R. A., Iyansyah, M. I., Wijaya, B. A., \& Kurniawati, M. F. (2021). Implementasi Strategi Komunikasi Kesehatan dalam Meyakinkan Masyarakat untuk Pelaksanaan Vaksinasi COVID-19 di Kabupaten
Barito Kuala. Jurnal Sains Sosio Humaniora, 5(1), 409-419. 